\title{
The effect of isovalent substitutions and dopants of $3 d$-metals on the properties of ferroelectrics- semiconductors
}

\author{
O.I.V'yunov; L.L.Kovalenko, A.G.Belous \\ V.I.Vernadskii Institute of General and Inorganic Chemistry \\ 32/34 Palladina Ave., 03680 Kyiv-142, Ukraine
}

Received September 2, 2002

\begin{abstract}
Electrophysical properties and microstructure of PTCR ceramics of the system $(\mathrm{Ba}, \mathrm{Ca}, \mathrm{Sr}, \mathrm{Y}) \mathrm{TiO}_{3}+y \% \mathrm{Mn}$ have been investigated. It has been shown that manganese ions increase the potential barrier at grain boundaries and form a high-resistance outer layer in $(\mathrm{Ba}, \mathrm{Ca}, \mathrm{Sr}, \mathrm{Y}) \mathrm{TiO}_{3}$ ceramics. The resistance of grains, outer layers and grain boundaries, the values of temperature coefficient of resistance as well as the varistor effect as a function of manganese content of PTCR materials have been investigated.
\end{abstract}

Key words: PTCR, manganese dopant, varistor effect, microstructure, potential barrier, complex impedance

PACS: $61.66 . F n, 77.80 . B h, 78.40 . F y$

\section{Introduction}

Positive temperature coefficient of resistance (PTCR) occurs in ferroelectric semiconducting ceramics based on doped barium titanate near Curie point due to the formation of potential barriers at grain boundaries [1]. Therefore, PTCR ceramics are synthesized in the conditions at which semiconducting grains and highresistance grain boundaries are formed. In particular, this is achieved when yttrium ions are partially substituted for barium ions and grain boundaries oxidized during sintering of ceramics in the air. Complex impedance $\left(Z^{*}\right)$ and complex electric modulus $\left(M^{*}\right)$ analysis in a wide frequency range showed the presence of semiconducting grains, high-resistance grain boundaries and outer layers between grains and grain boundaries in PTCR materials. These areas of PTCR ceramics are electrically non-uniform and can be represented by an equivalent circuit, which includes three parallel $R C$-elements connected in series [2-4]. The low magnitude of resistivity change in the PTCR region, viz. ratio of maximum $\left(\rho_{\max }\right)$ to minimum $\left(\rho_{\min }\right)$ resistivity, and large varistor effect, viz. reduction of resistivity under external electric

*E-mail: vyunov@ionc.kar.net 
field, are the basic difficulties in the use of barium-titanate-based PTCR materials in the devices working at high strengths of electric field. The magnitude of varistor effect can be estimated from the dependence of normalized resistivity $\rho_{\mathrm{E}} / \rho_{0}$, where $\rho_{\mathrm{E}}$ and $\rho_{0}$ are resistivity of the sample at zero and nonzero voltage, on the electric field strength (E). Earlier investigations of PTCR barium titanate [5] showed that the magnitude of varistor effect correlates with the average grain size of ceramics, namely, the varistor effect is smaller in fine-grained ceramics. Both average grain size and the varistor effect decrease at partial substitution of calcium and strontium for barium in PTCR barium titanate $(\mathrm{Ba}, \mathrm{Ca}, \mathrm{Sr}, \mathrm{Y}) \mathrm{TiO}_{3}$. The magnitude of resistivity change in this case remains unchanged. Besides, the partial isovalent substitution in the barium site of barium titanate shifts the Curie point towards low-temperature range, and this expands the area of application of PTCR-materials. However, the low magnitude of resistivity change in PTCR area does not permit to utilize the above materials at high strengths of the electric field. The decrease in varistor effect and the increase in the magnitude of resistivity change are also attributed to the increase in the resistance of grain boundaries [6,7]. In particular, this occurs when the synthesized materials are doped with acceptors (for example, manganese) [8]. High-resistance grain boundaries in manganese-doped PTCR materials are formed due to redox transformations of manganese oxides in the same temperature range in which redox processes, accompanied with the formation of trivalent titanium, proceed [9]. However, the information concerning the distribution of manganese dopant in a polycrystalline material is scantily presented in the literature. This does not permit to explain the formation mechanisms of PTCR effect, as well as to control the properties of the ceramics based on barium titanate with manganese dopant.

Therefore, the aim of this work was to study the distribution of manganese ions in $(\mathrm{Ba}, \mathrm{Ca}, \mathrm{Sr}, \mathrm{Y}) \mathrm{TiO}_{3}$ ceramics and its effect on the properties of grains, outer grain layers and grain boundaries of PTCR ceramics.

\section{Experimental}

Extra-pure $\mathrm{BaCO}_{3}, \mathrm{CaCO}_{3}, \mathrm{SrCO}_{3}, \mathrm{TiO}_{2}, \mathrm{Y}_{2} \mathrm{O}_{3}, \mathrm{SiO}_{2}, \mathrm{MnSO}_{4}$ and water solution of ammonia were used as starting reagents. Powders were ball-milled in agate mortar. In order to reduce the pollution of mixed powders during the milling, the working surfaces of crushing cylinders were covered with vacuum rubber. Uniform distribution of manganese dopant was ensured by its precipitation from solutions. Electrophysical properties of samples sintered at $1340-1360{ }^{\circ} \mathrm{C}$ have been investigated. The grain sizes in the ceramics were determined using X-ray microanalyser JCXA Superprobe 733 (JEOL, Japan). Aluminium electrodes were fabricated by burning in $\mathrm{Al}$ paste. Electrical properties of the ceramics were studied at direct and alternating current. Impedance analyzer PGSTAT-30 (Solartron) was used for measurements in the frequency range $100 \mathrm{~Hz}-1 \mathrm{MHz}$, and BM-560 Q-meter was used for measurements in the frequency range $50 \mathrm{kHz}-35 \mathrm{MHz}$. Equivalent circuit and values of its components were determined using Frequency Response Analyzer 4.7 PC program. 


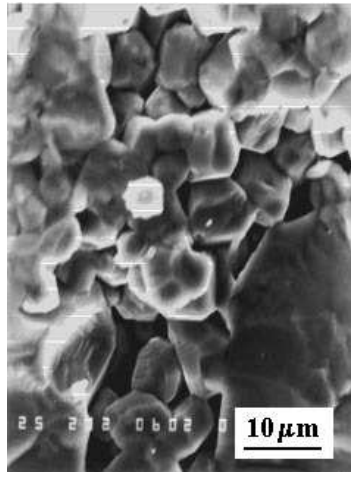

(a)

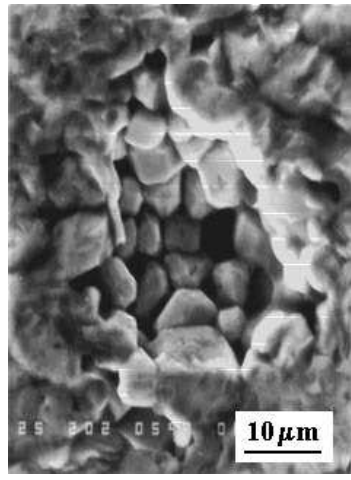

(b)

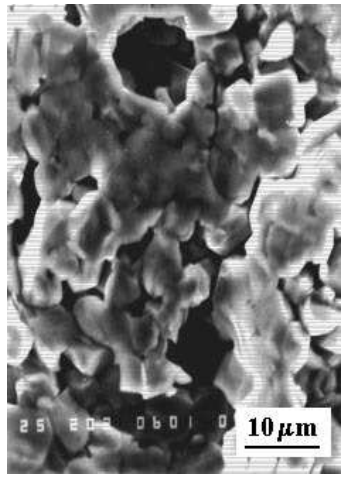

(c)

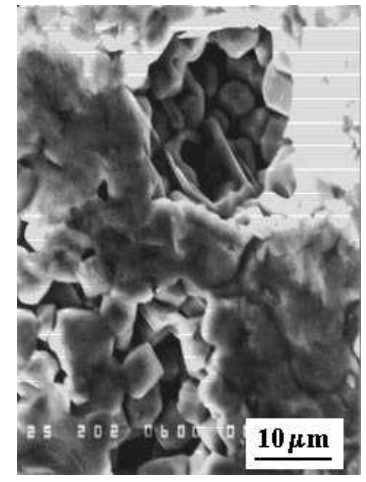

(d)

Figure 1. Microstructure of PTCR ceramics in (Ba,Ca,Sr,Y) $\mathrm{TiO}_{3}+y$ mol.\% Mn system: $y=0$ (a), 0.002 (b), 0.006 (c), 0.01 (d), $\times 1000$.

\section{Results and discussion}

The average grain size of PTCR ceramics of the system (Ba,Ca,Sr,Y) $\mathrm{TiO}_{3}$ does not change with manganese content (figure 1). The temperature dependence of resistivity of PTCR ceramics can be schematically divided into 3 ranges (figure 2). Range I extends from room to phase transition temperature and is characterized by relatively low resistivity which decreases with temperature. Range II lies above the phase transition temperature where a rapid growth of resistivity is observed (PTCR effect). Range III exists at a high temperature and is characterized by high resistivity which decreases with temperature. When the ceramics are doped with manganese, the magnitude of resistivity change in PTCR area increases (see figure 2), and the varistor effect essentially decreases (figure 3). On the basis of the above fact it may be assumed that the potential barrier at grain boundaries increases with manganese content.

$\rho, \Omega \cdot \mathrm{cm}$

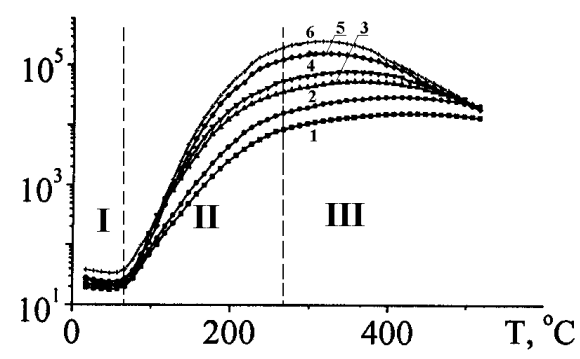

Figure 2. Resistivity of PTCR ceramics of $(\mathrm{Ba}, \mathrm{Ca}, \mathrm{Sr}, \mathrm{Y}) \mathrm{TiO}_{3}+y \mathrm{~mol} . \% \mathrm{Mn}$ system versus temperature; $y=0(1)$, $0.002(2), 0.006(3), 0.01(4), 0.02(5)$, $0.03(6)$.

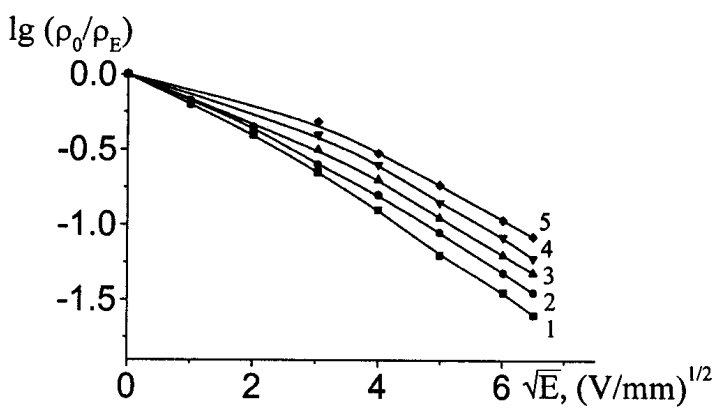

Figure 3. Normalized resistivity $\left(\lg \rho_{\mathrm{E}} / \rho_{0}\right)$ of PTCR ceramics of $(\mathrm{Ba}, \mathrm{Ca}, \mathrm{Sr}, \mathrm{Y}) \mathrm{TiO}_{3}+y$ mol.\% $\mathrm{Mn}$ system versus external electric field; $y=0$ (1), 0.002 (2), 0.006 (3), 0.01 (4), $T_{\text {meas. }}=20{ }^{\circ} \mathrm{C}$. 

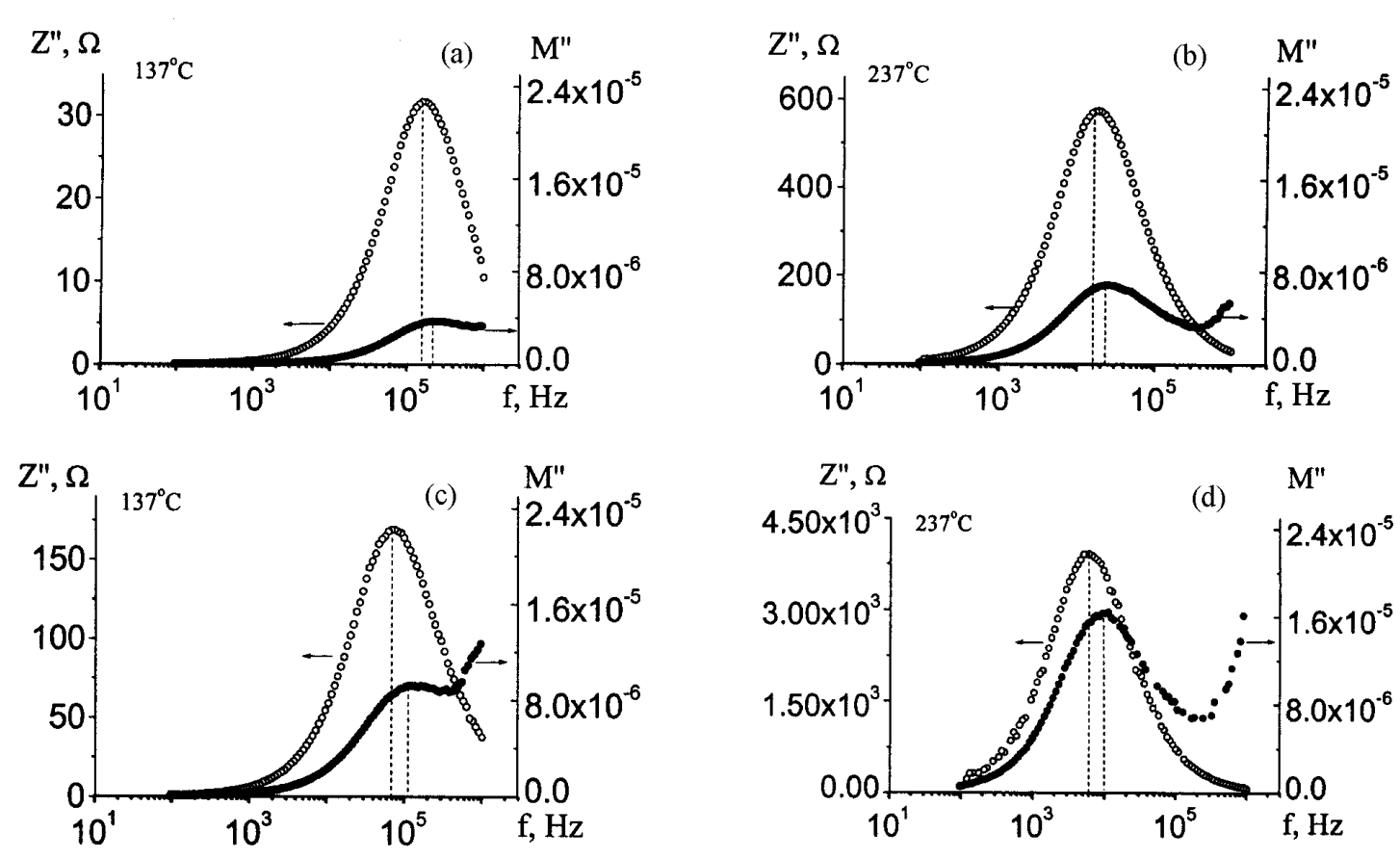

Figure 4. Imaginary components of complex impedance $Z^{\prime \prime}$ and electric modulus $M^{\prime \prime}$ of PTCR ceramics of $(\mathrm{Ba}, \mathrm{Ca}, \mathrm{Sr}, \mathrm{Y}) \mathrm{TiO}_{3}(\mathrm{a}, \mathrm{b})$ and $(\mathrm{Ba}, \mathrm{Ca}, \mathrm{Sr}, \mathrm{Y}) \mathrm{TiO}_{3}+$ $0.01 \mathrm{~mol} . \% \mathrm{Mn}$ systems (c, d) versus frequency at various temperatures.

The results of frequency investigations of the PTCR ceramics can be analyzed as four types of dependences: of complex impedance $\left(Z^{*}\right)$, complex admittance $\left(Y^{*}\right)$, complex permittivity $\left(\epsilon^{*}\right)$ and complex electric modulus $\left(M^{*}\right)$. The complex quantities are interrelated: $M^{*}=1 / \epsilon^{*}=j \omega C_{o} Z^{*}=j \omega C_{o}\left(1 / Y^{*}\right)$ (where $j=\sqrt{-1}$ ) For an analysis, the results of investigations were presented as frequency dependences of the imaginary components of complex impedance $Z^{\prime \prime}$ and complex electric modulus $M^{\prime \prime}$, which for a parallel $R C$ element are described by the equations $[2-4,10,11]$ :

$$
Z^{\prime \prime}=R \cdot \frac{\omega R C}{1+(\omega R C)^{2}}, \quad M^{\prime \prime}=\frac{\epsilon_{0}}{C} \cdot \frac{\omega R C}{1+(\omega R C)^{2}},
$$

where $\omega=2 \pi f$ is angular frequency ( $f$ denote frequency in $\mathrm{Hz}$ ) and $\epsilon_{0}$ is the permittivity of free space $\left(8.854 \cdot 10^{-14} \mathrm{~F} \cdot \mathrm{cm}^{-1}\right)$.

From equations (1) it follows that:

$$
\omega_{\max }=\frac{1}{R C}, \quad Z_{\max }^{\prime \prime}=\frac{R}{2}, \quad M_{\max }^{\prime \prime}=\frac{\epsilon_{0}}{2 C} .
$$

Equations (2) show that the shift of the peaks $Z_{\max }^{\prime \prime}$ and $M_{\max }^{\prime \prime}$ in frequency $\left(\omega_{\max }\right)$ is associated with a change in the values of both capacity and resistance in the corresponding $R C$ element of the equivalent circuit. The $Z_{\max }^{\prime \prime}$ value is sensitive to the change in the resistance, and the $M_{\max }^{\prime \prime}$ value is affected by the capacity.

Figure 4 shows frequency dependences of $Z^{\prime \prime}$ and $M^{\prime \prime}$ of samples of the systems $(\mathrm{Ba}, \mathrm{Ca}, \mathrm{Sr}, \mathrm{Y}) \mathrm{TiO}_{3}$ and $(\mathrm{Ba}, \mathrm{Ca}, \mathrm{Sr}, \mathrm{Y}) \mathrm{TiO}_{3}+y$ mol.\% Mn, investigated at various 

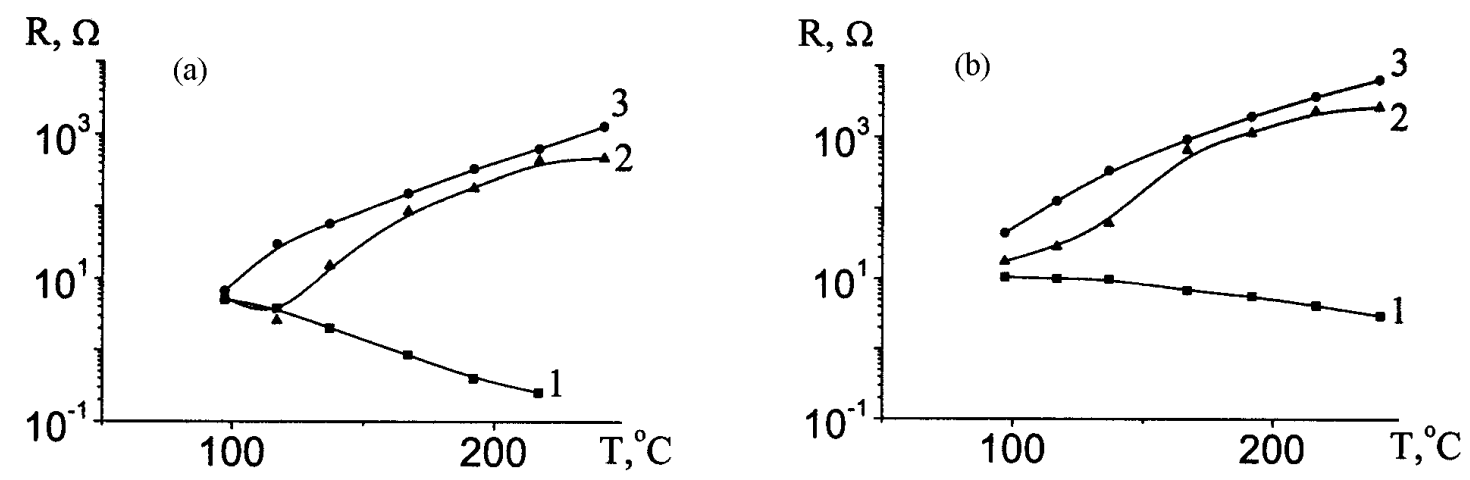

Figure 5. Resistance of grain (1), outer layer (2) and grain boundary (3) of PTCR ceramics of the $(\mathrm{Ba}, \mathrm{Ca}, \mathrm{Sr}, \mathrm{Y}) \mathrm{TiO}_{3}$ (a) and $(\mathrm{Ba}, \mathrm{Ca}, \mathrm{Sr}, \mathrm{Y}) \mathrm{TiO}_{3}+0.01 \mathrm{~mol} \% \mathrm{Mn}$ systems (b) versus temperature.

temperatures. The plot of $Z^{\prime \prime}(f)$ exhibits one peak, and the plot of $M^{\prime \prime}(f)$ exhibits two peaks: one in the medium-frequency range $\left(10^{4}-10^{5} \mathrm{~Hz}\right)$ and the other in the high-frequency ( $>10^{8} \mathrm{~Hz}$ ) range. The positions of $Z_{\max }^{\prime \prime}$ and $M_{\max }^{\prime \prime}$ do not coincide in frequency. This may be accounted for by the fact that the behavior of these maxima is affected by different electroactive ceramic regions. The change in the value and position of the maximum in the plot of $Z^{\prime \prime}(f)$ is associated with the change in the electrophysical properties of the grain boundary, and that of $M^{\prime \prime}(f)$ at $10^{4}-10^{5} \mathrm{~Hz}$ and at $>10^{8} \mathrm{~Hz}$ is associated with the change in the electrophysical properties of the grain outer layer and the grain, respectively [2-4]. Figure 4 shows that the frequency of $Z_{\max }^{\prime \prime}$ in $(\mathrm{Ba}, \mathrm{Ca}, \mathrm{Sr}, \mathrm{Y}) \mathrm{TiO}_{3}$ ceramics decreases and the value of $Z_{\max }^{\prime \prime}$ increases with the increase of temperature. This is due, according to equations (2), to an increase in the resistance of the grain boundary. The positions of $M_{\max }^{\prime \prime}$ in the medium-frequency range slightly shifts with the increase of temperature, and the value of $M_{\max }^{\prime \prime}$ essentially increases. This is due, according to equation (2), to a decrease in the capacitance and an increase in the resistance of the outer layer of the grain. A calculation carried out on the basis of our experimental data corroborated the above conclusion.

Temperature dependences of the resistance of electrically different areas of the PTCR ceramics $(\mathrm{Ba}, \mathrm{Ca}, \mathrm{Sr}, \mathrm{Y}) \mathrm{TiO}_{3}$ and $(\mathrm{Ba}, \mathrm{Ca}, \mathrm{Sr}, \mathrm{Y}) \mathrm{TiO}_{3}+0.01 \mathrm{~mol} . \% \mathrm{Mn}$ are shown in figure 5 . The variation of the resistance of the outer layer with temperature is similar to that of the grain boundary. Hence, the PTCR effect in (Ba, Ca, Sr,Y) $\mathrm{TiO}_{3}$ ceramics without manganese dopant occurs due to a change in electrophysical properties of the grain boundaries and the outer layers.

Temperature dependences of capacitances of (Ba,Ca,Sr,Y) $\mathrm{TiO}_{3}$ PTCR ceramics are shown in figure 6 . The capacitance of the grain boundary of the PTCR ceramic slightly changes with temperature, and the capacitance of the outer layer varies with temperature by the Curie-Weiss law (figure 6a). The capacitance of the grain boundary and the outer layer decreases in manganese-doped ceramics (figure 6b).

The results of investigations of PTCR $(\mathrm{Ba}, \mathrm{Ca}, \mathrm{Sr}, \mathrm{Y}) \mathrm{TiO}_{3}$ ceramics properties at room temperature as a function of manganese content are shown in figure 7 . As is 

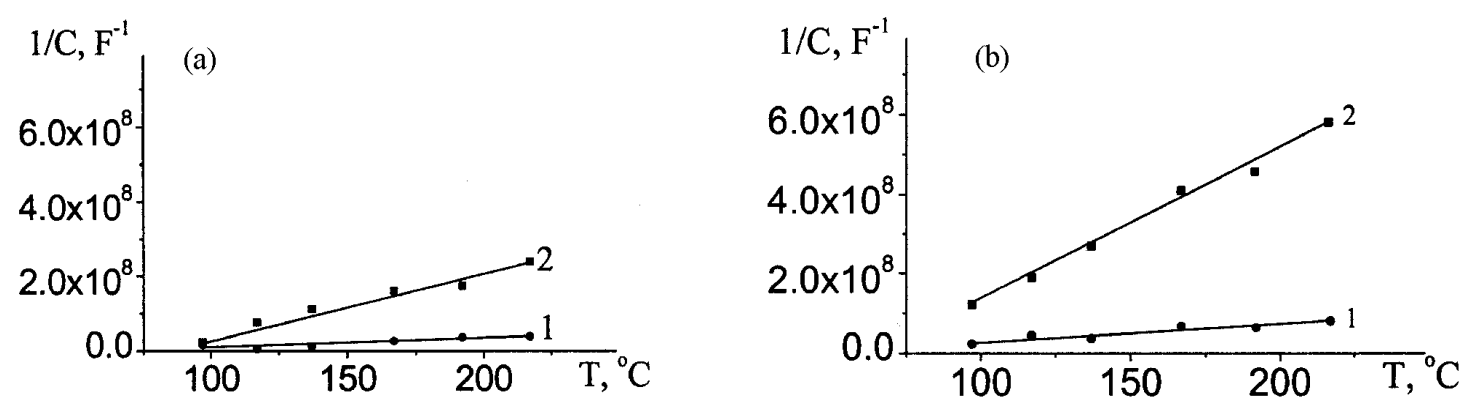

Figure 6. Inverse capacitance of grain boundary (1) and outer layer (2) of the systems (Ba,Ca,Sr,Y) $\mathrm{TiO}_{3}$ (a) and (Ba,Ca,Sr,Y) $\mathrm{TiO}_{3}+0.01$ mol.\% Mn (b) versus temperature.

evident from the data presented, the grain boundary resistance increases, whereas the grain resistance remains practically unchanged with the increasing manganese content. This is due to the manganese being not incorporated into the whole bulk of PTCR barium titanate grain in the concentration range under study.

To ascertain the reason of the increase in the multiplicity of resistance change in the PTCR region of ceramics as a function of manganese content, the magnitude of the potential barrier at the grain boundary has been calculated. The variation of the resistance in the temperature range $c a \cdot 17-50{ }^{\circ} \mathrm{C}$ (see figure 2 , range I) and ca. $300-500{ }^{\circ} \mathrm{C}$ (see figure 2 , range III) is described by the equations [1, 12]:

$$
\rho_{\mathrm{S}}=\rho_{0}^{\mathrm{I}} \cdot \mathrm{e}^{\frac{E_{\mathrm{a}}^{\mathrm{I}}}{k T}}, \quad \rho_{\mathrm{d}}=\rho_{0}^{\mathrm{III}} \cdot \mathrm{e}^{\frac{E_{\mathrm{a}}^{\mathrm{III}}}{k T}},
$$

where $\rho_{0}$ is a constant for material [13]; $E_{\mathrm{a}}$ is the activation energy of conductivity; $k$ is Boltzmann constant $\left(1.38 \cdot 10^{-23} \mathrm{~J} / \mathrm{K}=8.62 \cdot 10^{-5} \mathrm{eV} / \mathrm{K}\right)$.

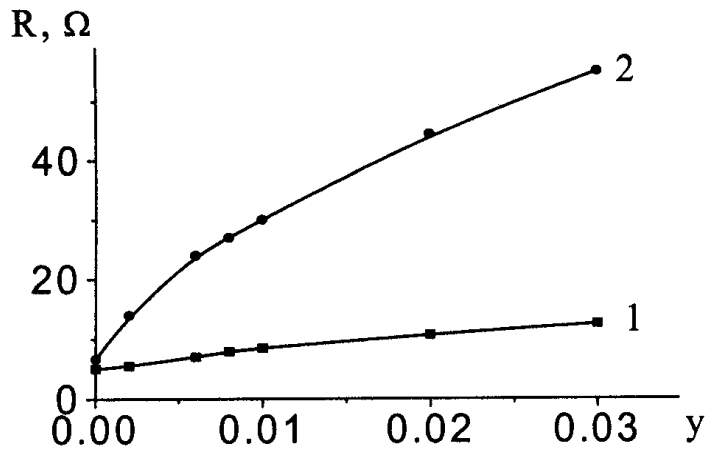

Figure 7. Resistance of grain (1) and grain boundary (2) of PTCR ceramics of $(\mathrm{Ba}, \mathrm{Ca}, \mathrm{Sr}, \mathrm{Y}) \mathrm{TiO}_{3}+y \mathrm{~mol} . \% \mathrm{Mn}$ system versus $\mathrm{Mn}$ content; $T_{\text {meas. }}=$ $20{ }^{\circ} \mathrm{C}$.

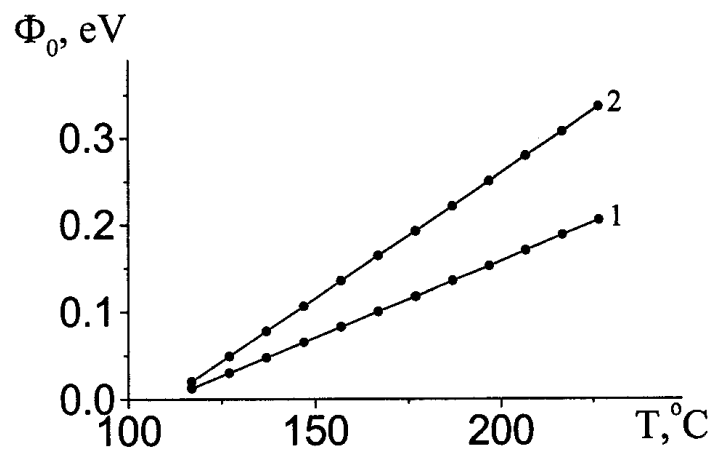

Figure 8. Potential barrier at grain boundaries $\left(\Phi_{0}\right)$ of PTCR ceramics of $(\mathrm{Ba}, \mathrm{Ca}, \mathrm{Sr}, \mathrm{Y}) \mathrm{TiO}_{3}+y$ mol.\% Mn system versus temperature; $y=0(1)$, 0.01 (2). 
Table 1. The effect of manganese content on the characteristics of temperature dependence of the resistance of PTCR ceramics (Ba, Ca,Sr, $\mathrm{Y}) \mathrm{TiO}_{3}$.

\begin{tabular}{|c|c|c|c|c|c|}
\hline \multirow{2}{*}{$\begin{array}{c}\text { Manganese } \\
\text { content, mol.\% }\end{array}$} & \multicolumn{2}{|c|}{ Range I } & Range II & \multicolumn{2}{c|}{ Range III } \\
\cline { 2 - 6 } & $R_{0}^{\mathrm{I}}, \Omega$ & $E_{\mathrm{a}}^{\mathrm{I}}, \mathrm{eV}$ & $n_{\mathrm{D}} \cdot b^{2}, \mathrm{~cm}^{-1}$ & $R_{0}^{\mathrm{III}}, \Omega$ & $E_{\mathrm{a}}^{\mathrm{III}}, \mathrm{eV}$ \\
\hline 0 & 4.2 & 0.04 & $3.2 \cdot 10^{8}$ & 2000 & 0.13 \\
\hline 0.002 & 4.7 & 0.04 & $3.6 \cdot 10^{8}$ & 800 & 0.22 \\
\hline 0.006 & 4.8 & 0.04 & $4.2 \cdot 10^{8}$ & 120 & 0.36 \\
\hline 0.01 & 5.2 & 0.04 & $5.4 \cdot 10^{8}$ & 36 & 0.44 \\
\hline 0.02 & 5.8 & 0.04 & $5.5 \cdot 10^{8}$ & 0.7 & 0.69 \\
\hline 0.03 & 8.2 & 0.04 & $5.8 \cdot 10^{8}$ & 0.5 & 0.72 \\
\hline
\end{tabular}

The variation of the resistance in the temperature range $c a .100-300{ }^{\circ} \mathrm{C}$, where a PTCR effect manifests itself, is usually described in terms of the Heywang model [1]:

$$
\rho=\alpha \cdot \rho_{\mathrm{S}} \cdot \mathrm{e}^{\frac{\Phi_{0}(T)}{k T}},
$$

where $\alpha$ is the geometric factor; $\Phi_{0}(\mathrm{~T})$ is the height of the potential barrier at the grain boundary:

$$
\Phi_{0}(T)=\frac{e^{2} \cdot n_{\mathrm{D}} \cdot b^{2}}{2 \cdot \epsilon_{i}(T) \cdot \epsilon_{0}}
$$

$e$ is the electron charge; $n_{\mathrm{D}}$ is the electron volume concentration; $b$ is the potential barrier thickness $\left(2 b=n_{\mathrm{S}} / n_{\mathrm{D}}\right.$, where $n_{\mathrm{S}}$ is surface concentration of acceptor states); $\epsilon_{i}(T)$ is grain permittivity which varies in ferroelectrics by the Curie-Weiss law: $\epsilon_{i}(T)=C / T-\Theta$ (where $C$ is Curie constant and $\Theta$ is Curie temperature).

From equations (3) and (4) we can get:

$$
\rho=\alpha \cdot \rho_{0} \cdot \mathrm{e}^{\frac{E_{0}^{\mathrm{I}}}{k T}} \cdot \exp \frac{e^{2} \cdot n_{\mathrm{D}} \cdot b^{2}(T-\Theta)}{2 \cdot \epsilon_{0} \cdot C \cdot k T} .
$$

The results of calculations for $(\mathrm{Ba}, \mathrm{Ca}, \mathrm{Sr}, \mathrm{Y}) \mathrm{TiO}_{3}$ ceramics according to equations (3) and (6) show that in the temperature range I the resistance remains unchanged and conductivity activation energy $E_{\mathrm{a}}^{\mathrm{I}}$ decreases with the increasing manganese content, whereas in the temperature range III the resistance decreases and conductivity activation energy increases (table 1). The magnitude of the potential barrier at the grain boundaries of PTCR barium titanate, which accounts for the increase in the multiplicity of resistance change in the PTCR region, were calculated using equation 5 (figure 8) and agreed with the literature data [14].

Thus, the investigations of the manganese-doped PTCR ceramics based on ( $\mathrm{Ba}, \mathrm{Ca}, \mathrm{Sr}, \mathrm{Y}) \mathrm{TiO}_{3}$ carried out by us over a wide frequency and temperature range showed that the manganese content slightly affects the grain resistance. Manganese ions are mainly at the grain boundaries and in the grain outer layer and act as acceptors. This greatly improves the properties of PTCR materials: the multiplicity of the resistance change in the PTCR region increases, and the varistor effect decreases. 


\title{
References
}

1. Heywang W. // J. Am. Ceram. Soc., 1964, vol. 47, No. 10, p. 484-490.

2. Sinclair D.C., Morrison F.D., West A.R. // Internat. Ceram., 2000, vol. 2, p. 33-37.

3. Morrison F.D., Sinclair D.C., West A.R. // J. Am. Ceram. Soc., 2001, vol. 84, No. 2, p. $474-476$.

4. Morrison F.D., Sinclair D.C., West A.R. // J. Am. Ceram. Soc., 2001, vol. 84, No. 3, p. $531-538$.

5. Belous A.G., Kolodyazhnyi T.V., Yanchevskii O.Z. // Ukr. Chem. Journal., 1995, vol. 61, No. 8, p. 86-89 (in Russian).

6. Pavlov A.N., Rayevskii I.P. // J. Tech. Physics, 1997, vol. 67, No. 12, p. 21-25 (in Russian).

7. Gaosheng L., Roseman R.D. // J. Materials Science Letters, 1999, vol. 18, p. 18751878.

8. Yanchevskii O.Z., V'yunov O.I., Belous A.G., Vasiliev A.D. - In: Digest "Electron Microscopy and Materials Strength". Kyiv, 1997, p. 106-113 (in Russian).

9. Kostikov Yu.D., Leikina B.B. // Inorg. Materials, 1990, vol. 26, No. 4, p. 884-886.

10. Jonker G.H. // Solid-State Electron., 1964, vol. 7, p. 895-903.

11. Dutta P.K., Alim M.A. // Jpn. J. Appl. Phys., 1996, vol. 35, No. 12A, p. 6145-6152.

12. Heywang W. // J. Mater. Sci., 1971, No. 6, p. 1214-1226.

13. Wang D.Y., Umeya K. // J. Am. Ceram. Soc., 1990, vol. 73, No. 3, p. 669-677.

14. Hari N., Padmini P., Kutty T. // J. Mater. Sci., 1997, vol. 8, p. 15-22.

\section{Вплив ізовалентних заміщень і домішок $3 d$-металів на властивості сегнетоелектриків-напівпровідників}

\author{
О.І.В'юнов, Л.Л.Коваленко, А.Г.Білоус
}

Інститут загальної та неорганічної хімії ім. В.І.Вернадського 03680 Київ-142, просп. Палладіна, 32/34

Отримано 2 вересня 2002 р.

Метою даної роботи було вивчення впливу йонів мангану на властивості областей ПТКО кераміки на основі $(\mathrm{Ba}, \mathrm{Ca}, \mathrm{Sr}, \mathrm{Y}) \mathrm{TiO}_{3}$, що відрізняються за електричними властивостями. Було знайдено, що ріст вмісту мангану в кераміці на основі титанату барію збільшує опір границь і зовнішніх шарів зерен, але практично не змінює опору зерен; при цьому потенціальний бар'єр на границях зерен зростає. Проведені дослідження ПТКО кераміки на основі титанату барію в широкому частотному і температурному інтервалах дозволяють стверджувати, що йони мангану знаходяться переважно на границях зерен і слабо впливають на опір зерен. Такий розподіл домішки мангану суттєво покращує властивості ПТКО матеріалів.

Ключові слова: ПТКО, домішка мангану, варисторний ефект, мікроструктура, потенціальний бар'єр, комплексний імпеданс

PACS: $61.66 . F n, 77.80 . B h, 78.40 . F y$ 